\title{
MATERIAŁY
}

Michat Piekarski

DOI: 10.14746/BHW.2016.34.7

Instytut Historii Nauki PAN Warszawa

\section{Ks. Waclaw Sierakowski - propagator wiedzy o muzyce i organizator szkolnictwa muzycznego w okresie działalności Komisji Edukacji Narodowej}

\begin{abstract}
Father Wacław Sierakowski: Propagator of Musical Knowledge and Organiser of Musical Education in the Times of the Commission of National Education

In the second half of the $18^{\text {th }}$ century, musical education in Poland was poor. The Commission of National Education (1773-1793) did not take music into account in its projects. The individual willing to change the situation was Father Wacław Sierakowski (1741-1806), provost of the Wawel Cathedral in Krakow. He played a significant role in the musical life of the city as an organiser of public concerts and founder of a private music school. In 1795-1796, he published a three-volume musical textbook, The Art of Music for Young Polish People (Sztuka muzyki dla młodzieży krajowej), one of the first musical textbooks in the Polish language. In Sierakowski's publication the stress was put on the social and national value of music. The first volume also featured Sierakowski's petition from 1792, intended for submission before the Sejm (Polish Parliament), in which the author propounded the idea of the state taking over musical education and establishing a major statesponsored music school in Krakow (Alumnatus Vocalistarum). These plans were never carried out as the third partition of Poland ensued in 1795.
\end{abstract}

Keywords: history of education, music, Krakow

Wychowanie muzyczne nie znajdowało się w obrębie głównych zainteresowań Komisji Edukacji Narodowej, choć istniały w Rzeczypospolitej niemałe tradycje w tym zakresie. W 2 poł. XVIII w. doszło wręcz do upadku nauczania muzyki na ziemiach polskich. Stan ten najlepiej zauważył ks. Wacław Sierakowski (ur. 1741 r. w Bogusławicach, zm. 1806 r. w Krakowie), kanonik i proboszcz katedry na Wawelu ${ }^{43}$.

${ }^{43}$ Ks. W. Sierakowski pochodził z arystokratycznej rodziny, był synem chorążego Romana Sierakowskiego oraz bratankiem arcybiskupa lwowskiego Wacława Hieronima Sierakowskiego, pod którego opiekę oddano go w wieku 8 lat. Już w młodości został przeznaczony do stanu duchownego. Kształcił się w kolegium jezuickim w Krośnie oraz Przemyślu. Studiował teologię w Warszawie (u księży misjonarzy) i Jarosławiu (w seminarium duchownym). Odbył też studia w Rzymie (1763-1767), gdzie przyjął święcenia kapłańskie. Po stu- 
Zdaniem Tadeusza Przybylskiego, ks. Sierakowski odegrał niemałą rolę w życiu muzycznym Krakowa, które po wojnach XVII w. znacznie ucierpiało, okres rozwoju znajdując jedynie w latach 1698-1734 dzięki Grzegorzowi Gerwazemu Gorczyckiemu, po którego śmierci aż do czasów Sierakowskiego ograniczało się ono wyłącznie do kilku kapel (rorantystów, katedralnej, mariackiej i jezuickiej - najlepszej w Polsce ${ }^{44}$, skasowanej w 2 poł. XVIII w. oraz kapeli akademickiej przy kościele św. Anny). Ks. Sierakowski w 1781 r. w swoim prywatnym domu przy ul. Grodzkiej 116 założył prywatną szkołę śpiewu (działała do 1787 r.), z której rekrutowali się wykonawcy uprawiający muzykę w katedrze na Wawelu ${ }^{45}$. Zaangażował do niej jako nauczycieli dobrych muzyków - jak np. Jakub Gołąbek ${ }^{46}$. Podobno uczniowie ze szkoły Sierakowskiego byli tak dobrze przygotowani, że angażowano ich także do wykonywania utworów z okazji innych okoliczności, np. podczas wizyty Stanisława Augusta Poniatowskiego, który w 1787 r. przybył do Krakowa na posiedzenie ${ }^{47}$. Do wychowanków szkoły ks. Sierakowskiego należał m.in. wybitny śpiewak - Jan N. Szczurowski. W tym czasie z udziałem uczniów i nauczycieli swojej szkoły organizował w swoim mieszkaniu koncerty wokalno-instrumentalne - na wzór concerts spirituels ${ }^{48}$ - na które zapraszał licznych gości ${ }^{49}$. Świadczy to o umiejętności wykorzystania doświadczenia nabytego we Francji.

Działalność ks. Sierakowskiego na polu edukacji muzycznej wypełniła też częściowo lukę po zlikwidowaniu w 1773 r. jezuickiej bursy muzycznej, działającej (także przy ulicy Grodzkiej) od połowy XVII w., która obejmowała nie tylko kapelę obsługującą kościół pw. św. Piotra i Pawła, ale także stała się prawdziwą szkołą muzyczną, będącą największą tego typu instytucją w Krakowie (licząc 50-60 bursarzy) $)^{50}$.

Ks. Sierakowski, widząc jednocześnie potrzebę podniesienia poziomu rozrywki i muzycznej kultury miasta, w roku 1784 sprowadził do Krakowa pierwszą stałą włoską trupę operową, której chór zasilali uczniowie jego szkoły (teatr działał do 1794 r. w Pałacu

diach przebywał w Paryżu. Po powrocie do Polski (1769) od 1780 r. pełnił obowiązki prefekta krakowskiej kapeli katedralnej Zob. E. Aleksandrowska, [hasło:] Sierakowski Wacław, w: Polski słownik biograficzny, red. H. Markiewicz, t. XXXVII, Kraków 1996-1997, s. 313.

44 Zdaniem A. Chybińskiego najlepszą szkołą muzyczną w Rzeczypospolitej była bursa jezuicka w Krakowie. A. Chybiński, Przyczynki do historii krakowskiej kultury muzycznej w XVII i XVIII wieku, „Wiadomości Muzyczne" 1925, nr 7, s. 159.

45 T. Przybylski, Wacław Sierakowski - działacz muzyczny Krakowa czasów Oświecenia (1741-1806), „Muzyka” nr 1, 1971, s. 54.

46 J. Gołąbek (1739 na Śląsku - 1789 w Krakowie), działał kolejno: w kapeli kościoła Mariackiego i w kapeli katedralnej na Wawelu, pracując jednocześnie także jako nauczyciel śpiewu w szkole muzycznej ks. W. Sierakowskiego przez cały okres jej istnienia, brał udział w organizowanych przez niego koncertach. Komponował utwory instrumentalne (m.in. 6 symfonii) oraz cykle mszalne i kantaty. A. Nowak-Romanowicz, [hasło:], Gołąbek Jakub, w: Encyklopedia muzyczna PWM, red. E. Dziębowska, t. 3, Kraków 1987, s. $372-373$.

47 A. Sowiński, Słownik muzyków polskich dawnych i nowoczesnych, Paryż 1874, s. 336.

${ }^{48}$ Concerts spirituels to nazwa kapeli organizującej w Paryżu od 1726 r. publiczne koncerty muzyki sakralnej i instrumentalnej.

49 E. Aleksandrowska, [hasło:] Sierakowski Wacław, w: Polski słownik biograficzny, s. 313.

${ }^{50}$ J. Kochanowicz, Geneza, organizacja i działalność jezuickich burs muzycznych, Kraków 2002, s. 73-75, 284. 
Spiskim, mieszczącym się przy Rynku pod nr 34) ${ }^{51}$. Ks. Sierakowski przez swoje działania organizacyjne obejmujące prowadzenie szkoły muzycznej, organizację koncertów i sprowadzenie trupy operowej, ożywił tkwiace w marazmie życie muzyczne Krakowa ${ }^{52}$.

Tak ożywiona działalność ks. Sierakowskiego nie ograniczała się jednak jedynie do organizacji życia muzycznego. Pisał także książeczki będące poradnikami o różnej tematyce, dotyczące budownictwa, rolnictwa, zdrowia i prawa spadkowego ${ }^{53}$. Nie pominął przy tym także podręcznika do teorii muzyki.

\section{Sztuka muzyki dla młodzieży krajowej}

Z samego końca XVIII w. pochodzi rodzaj poradnika muzycznego - 3-tomowa Sztuka muzyki dla młodzieży krajowej wydana w Krakowie. Tom I ukazał się w roku 1795, dwa kolejne w 1796. W tomie I omówione zostały korzyści płynące z uprawiania muzyki, a w dalszej części - reguły dobrego śpiewania wraz z zagadnieniami melodyki, rytmiki, agogiki i dynamiki (z wyjaśnieniem wielu pojęć). Tom II to mała encyklopedia muzyczna, tom III - rozważania i praktyczne wskazówki wykonawcze (głównie w odniesieniu do muzyki kościelnej).

Sztuka muzyki dla młodzieży krajowej wypełnia stuletnią lukę w znanej nam do dziś tego rodzaju literaturze w języku polskim. Była to pierwsza drukowana praca od czasu wydania w Oliwie przez wileńskiego jezuitę ks. Wojciecha Tylkowskiego dziesięciotomowego dzieła Physica curiosa (1680-1691) ${ }^{54}$.

Sztukę muzyki można uznać za podsumowanie stanu wiedzy muzycznej w Rzeczypospolitej przedrozbiorowej. We „Wstępie”, mając nadzieję, że publikacja ta pobudzi zainteresowanie problematyką muzyczną, autor zaznaczył, że: A to ażeby chcacy korzystać z jej ozdób, zabaw $i$ wszelkich zysków, lepiej ja poznawszy poważali i gruntowniej $w$ tej sztuce postępowania krajowej młodzieży drogę edukacji torowali. Ks. Sierakowski dostrzegał potrzebę kształcenia w zakresie muzyki zarówno przez wydanie podręcznika, jak i powołanie regularnego szkolnictwa muzycznego. Dostrzegając brak na terenie Rzeczypospolitej profesjonalnej szkoły muzycznej widział degradację statusu samej muzyki, pisząc dalej we „Wstępie”: przy tylu w kraju naszym funduszach na muzyke, upodlona zostaje do tego punktu, iż żadnej szkoły normalnej nie ma, która mieć by katedrę publicz-

51 T. Przybylski, Wacław Sierakowski..., s. 58. Na potrzeby teatru specjalnie rozbudowano salę balową pałacu. Encyklopedia Krakowa, red. D. Kalisiewicz, Kraków 2000, s. 726.

52 T. Przybylski, Wacław Sierakowski..., s. 50, 59.

${ }_{53}$ P. Kołodziej, [hasło:] Sierakowski Wacław, w: Encyklopedia muzyczna PWM, red. E. Dziębowska, t. 9, Kraków 2007, s. 257.

${ }^{54}$ Sztuka muzyki Sierakowskiego wymieniana jest jako pedagogiczna literatura muzyczna także obok Tabulatury muzyki Jana Aleksandra Gorczyna (Kraków 1647) i Gramatyki muzycznej Mikołaja Pawłowicza Dyleckiego (Wilno 1675). T. Przybylski, ,, Sztuka muzyki” Wacława Sierakowskiego, „Muzyka” nr 3, 1968, s. 66. Z roku 1750 pochodzi także rękopiśmienna rozprawka autorstwa Marianny Moszyńskiej Principia albo początki należace uczącemu się śpiewania figurału pochodząca z sandomierskiego konwentu ss. klarysek. T. Przybylski, Z dziejów nauczania muzyki w Krakowie. Od średniowiecza do czasów współczesnych, Kraków 1994, s. 34. 
na w Akademii powinna ${ }^{55}$. Należy dodać, że mimo tak opisanego stanu rzeczy istniały w omawianym okresie w Warszawie dwie zawodowe szkoły muzyczne - nie były to jednak szkoły państwowe, lecz utrzymywane przez magnatów ${ }^{56}$. Muzyka jako przedmiot (zazwyczaj nadobowiązkowy) obecna była także w Szkole Kadetów i Szkole Rycerskiej oraz w wielu prywatnych pensjach - jednak, zwłaszcza w dwóch pierwszych, był to jedynie przedmiot uzupełniajacy, zaś pensje przysposobiały do grania głównie umuzykalnione damy, co w żaden sposób nie mogło rekomponsować braku szkoły stricte muzycznej. W roku wydania Sztuki muzyki od 15 lat nie istniało już w Wilnie seminarium nauczycielskie, w którego programie znajdował się śpiew chóralny oraz gra na klawikordzie i organach (funkcjonowało w latach 1775-1780 (1782)) $)^{57}$. Dla Sierakowskiego odczuwalny był zwłaszcza brak tego rodzaju szkoły w Krakowie, prowadzona bowiem przez niego szkoła muzyczna nie działała już od 8 lat. Postulat powołania w Rzeczypospolitej państwowej szkoły muzycznej ujął szerzej w wydrukowanym razem ze Sztuka muzyki projekcie poddanym sejmowi pt. Wykład materii podanych na Sejm w roku 1792 (będzie o nim jeszcze mowa).

W Sztuce muzyki ks. Sierakowski, przedstawiciel „wieku oświeconego”, podkreślił społeczną i narodową wartość muzyki. W zamieszczonym na początku Szkoły muzyki traktacie (zawierającym 48 stron) ukazane zostały Przyczyny które dla urzadzenia i ulepszenia tej tak ważnej umiejętności muzyki wszelka nasza usilność, staranie i chęć najżywsza wzruszać i pociagać powinny, wśród których w pierwszej kolejności obecne jest odwołanie do średniowiecznego systemu nauk: To naprzód, i że muzyka jest rzecz dobra chwalebna $i$ ze wszech miar budujaca. To $i$ że w klasie nauk wyzwolonych jest umieszczo$n a$, zaś w dalszych akapitach widnieje m.in. argument, iż ta zabawa lud wyższej rangi uszlachetnia, niższej poleruje, wszystkich mile bawiąc, gust dobry w nich wpaja ${ }^{58}$. Muzykę ks. Sierakowski uznał za naukę najrozleglejsza, najobfitsza, najmocniejsza, i na koniec najpotrzebniejszą $a^{59}$. Na tym przykładzie widać, co zauważył Tadeusz Przybylski, że Sierakowski zasadnicze wiadomości dotyczące muzyki wiązał ze scholastycznym sposobem wyprowadzenia wszelkich pojęć z religii (np. pochodzenie instrumentów muzycznych tłumaczył w oparciu o Bibllię), podając je czytelnikowi w formie moralizatorsko-dydaktycznej, tak typowej dla ludzi oświecenia, łącząc w ten sposób racjonalistyczne poglądy tej epoki ze średniowiecznymi pojęciami naukowymi ${ }^{60}$.

\footnotetext{
55 W. Sierakowski, Sztuka muzyki dla młodzieży krajowej, t. I, Kraków 1795 [Wstęp, s. 4-5].

${ }^{56}$ Pierwsza - przez ks. Stanisława Poniatowskiego, druga - ks. Marcina Lubomirskiego. Jan Prosnak, Kultura muzyczna Warszawy XVIII wieku, Kraków 1955, s. 221-222.

57 J. Prosnak, Kultura muzyczna Warszawy XVIII wieku, Kraków 1955, s. 217-218. Jak podaje A. Rutkowska seminarium wileńskie zamknięto w 1782 r. Po jego zamknięciu przez krótki okres bp Poniatowski próbował utrzymywać podobne szkoły w Kielcach (dla diec. krakowskiej) i Łowiczu (dla diec. gnieźnieńskiej). A. Rutkowska, Realizacja planów i postulatów Kom EN w zakresie wychowania muzycznego, w: PWSM w Warszawie, Sesja naukowo-artystyczna, Wychowanie muzyczne narodu w 200 rocznicę Komisji Edukacji Narodowej, Warszawa 1976, s. 33.

58 W. Sierakowski, op. cit., s. $1,8$.

59 Ibidem, s. 10.

60 T. Przybylski, ,, Sztuka muzyki”,.., s. 68.
} 
W podręczniku tym treści teoretyczne przeplatają się z rozważaniami z zakresu estetyki muzycznej. Jak stwierdził Zdzisław Jachimecki: styl pracy ma posmak prozy kaznodziejskiej ${ }^{61}$. Sierakowski w części teoretycznej zawarł wiadomości na temat muzycznych terminów, omawiając następnie naukę śpiewania (z przedstawieniem systemu solmizacyjnego w obrębie oktawy) i kwestie dotyczące instrumentów muzycznych. W tomie II próbował objaśnić szereg terminów muzycznych.

Sierakowski, pierwszy z polskich teoretyków, podał w tomie II Sztuki muzyki zasadniczy podział instrumentów muzycznych na 3 grupy, dęte i: 1. rżnięte smyczkiem, 2. wiatrem nadymane, 3. bębnione, czyli bite (dziś nazywamy je: chordofonami smyczkowymi, aerofonami i membranofonami) ${ }^{62}$, wymieniając całe znane na ziemiach polskich instrumentarium końca XVIII w. ${ }^{63}$ Warto dodać, że o nieuporządkowaniu wiedzy muzycznej świadczy fakt pominięcia przez ks. Sierakowskiego innych niż „rżnięte smyczkiem” instrumentów strunowych, jak: klawesyn czy lutnia oraz o nieowyodrębnieniu w takiej sytuacji instrumentów klawiszowych.

W petycji opublikowanej razem z I tomem Sztuki muzyki zatytułowanej Wykład materii podanych na Sejm w roku 1792 (o samej petycji mowa w dalszej części artykułu), w rozdziale IV przedstawił też koncepcję podziału gatunków muzycznych (rozgatunkowanie muzyki) na: muzykę obozowa (wojskową), pokojowa (kameralną), teatralna i kościelna ${ }^{64}$. Tylko ostatnim dwóm rodzajom przypisał możność wzbudzania u ludzi wzruszeń, co wynikało nie z własnej koncepcji autora, tylko stanowiło wyraz ogólnie panujących wówczas poglądów na muzykę ${ }^{65}$. Niestety nie towarzyszyła temu rozgraniczeniu już próba przyporządkowania odpowiednich utworów muzycznych. Widoczny jest tu także charakterystyczny dla prac Sierakowskiego dyletantyzm, nieraz zauważalny przez brak systematycznego wykładu poszczególnych elementów muzyki w konkretnych przeznaczonych do tego rozdziałach pracy, odznaczający się koniecznością szukania pokrewnych zagadnień w różnych tomach oraz nawet pracach (Wykład materii). W Sztuce muzyki zauważalny jest brak spójnego przedstawienia historii muzyki. W tomie I Sierakowski ograniczył się do wymienienia jedynie kilkunastu nazwisk - prawie samych XVIII-wiecznych kompozytorów i muzyków, jednak bez próby opisania ich twórczości ${ }^{66}$.

Na poglądy ks. Sierakowskiego na temat muzyki wpływ miała też wciąż aktualna zwłaszcza w estetyce niemieckiej, a narodzona we Włoszech w XVII w. - teoria afektów.

${ }^{61}$ Z. Jachimecki, Muzykologia i piśmiennictwo muzyczne w Polsce, Kraków 1949, s. 16. Sierakowski np. pisze, że: Ten najmilszy śpiewania talent przyrównać nie od rzeczy można do zakazanego rajskiego owocu. W. Sierakowski, op. cit., s. 45.

${ }^{62}$ Według aktualnego do dziś podziału instrumentów muzycznych stworzonego i opublikowanego w $1914 \mathrm{r}$. przez Curta Sachsa i Ericha Moritza von Hornbostela instrumenty muzyczne dzielimy na: aerofony, membranofony, idiofony i chordofony. Obecnie dodaje się jeszcze grupę elektrofonów.

63 T. Przybylski, ,, Sztuka muzyki”,.., s. 72.

${ }^{64}$ W. Sierakowski, op. cit., s. 185.

65 T. Przybylski, ,Sztuka muzyki”..., s. 74.

${ }^{66}$ Byli to m.in.: Jomelli, Pergolesi, Sachini, Cafarelli, Mazzanti, Paisielli, Porpora, Lotti, Tartini. W. Sierakowski, op. cit., s. 58. 
Zgodnie z ówczesnymi poglądami Sierakowski przyznawał prymat muzyce wokalnej nad instrumentalną ${ }^{67}$.

W rozdziale X („O narodowym języku”) postulował konieczność tworzenia muzyki do tekstów polskich żeby z muzyki odnosić pożytki, trzeba jej koniecznie $w$ narodowym języku doświadczać, bo inaczej skrytych serca namiętności nie ruszy ${ }^{68}$.

Na końcu Sztuki muzyki zawarł Sierakowski właściwe dla jego epoki dydaktyczne i moralizatorskie upomnienie, aby młodzież szkolna największa pilność łożyła do nabycia talentu muzyki i w ten sposób nabywając wiedzę - miała się formować na zacnych ludzi $i^{69}$.

Wywody Sierakowskiego często są dość zawiłe, i tak na prawdę nie tłumacząc często do końca co oznacza właściwy termin. Jak skonkludował Zdzisław Jachimecki było to zgoła nieopanowane grafomaństwo $i$ brak zdrowego rozsądku $w$ pojmowaniu oczywistych rzeczy ${ }^{70}$. Także Piotr Kołodziejczyk potwierdza, że publikacja ta jest również potwierdzeniem niskiego poziomu kultury muzycznej w ówczesnej Polsce, obfituje bowiem w błędy merytoryczne i nieporadności językowe ${ }^{71}$.

Jednocześnie, mimo wielu uchybień, nie można odmówić Sierakowskiemu oczytania w zakresie pism z czasów starożytnych, średniowiecznych, nowożytnych i jemu współczesnych. Korzystał m.in. z Dictionare de Musique J. J. Rousseau, odwołując się też bezpośrednio do tego nazwiska ${ }^{72}$. Znał też Sierakowski główne nurty w teorii muzyki, rozpropagowywane nieco wcześniej w Europie Zachodniej. Część poświęcona teorii muzyki wykazuje, że znał teorię harmonii Jeana-Philippe Rameau (do najbardziej znanych prac należały: Génération harmonique, Paryż 1737 i napisany we współpracy z Diderotem Démonstration du principe de l'harmonie, Paryż 1750), którego nowatorskie poglądy, rozpropagowane m.in. przez J. d'Alemberta, zaważyły na rozwoju nowożytnej teorii muzyki, dominując w nauce kompozycji, jak i w analitycznych oraz filozoficznych rozważaniach na temat związku muzyki z naturą. Teoria Rameau stała się też podstawą nauczania kompozycji w utworzonym w końcu XVIII w. konserwatorium w Paryżu ${ }^{73}$. To właśnie Rameau wprowadził fundamentalne terminy: tonique, dominante, sous-dominante, stające się podstawą teorii Hugo Riemanna (m.in. Die Natur der Harmonik, 1882, Grosse Kompositionslehre, t. 1-3, Berlin 1902-1913) - jednego z twórców muzykologii jako dyscypliny uniwersyteckiej w końcu XIX w. ${ }^{74}$ Wacław Sierakowski, wielokrotnie

${ }^{67}$ A. Nowak-Romanowicz, Klasycyzm 1750-1830, Warszawa 1995, s. 273-274.

${ }^{68}$ W. Sierakowski, op. cit., s. 150.

69 Ibidem, s. 154-155.

${ }^{70}$ Z. Jachimecki, Muzykologia i piśmiennictwo muzyczne w Polsce, Kraków 1949, s. 18.

${ }^{71}$ P. Kołodziej, [hasło:] Sierakowski Wacław, w: Encyklopedia muzyczna PWM, s. 257.

72 W. Sierakowski, op. cit., s. 126. A. Nowak-Romanowicz, Klasycyzm 1750-1830, s. 273.

73 A. Jarzębska, [hasło:] Rameau Jean-Philippe, w: Encyklopedia muzyczna PWM, red. E. Dziębowska, t. 8, Kraków 2004, s. 297, 300, 302.

${ }^{74}$ E. Dziębowska, [hasło:] Riemann Hugo, w: Encyklopedia muzyczna PWM, red. E. Dziębowska, t. 8, Kraków 2004, s. 391-392. 
powołując się na teorię Rameau ${ }^{75}$ i uznając w nim autorytet, zdobył się także na jego krytykę, nie uważając za całkowicie słuszny pogląd, że to harmonia rodzi melodię, jednocześnie jednak przyznając, że harmonię ciężko rozeznać od melodii. Zdaniem Aliny Nowak-Romanowicz przykład takiego niezdecydowania był typowy dla większości ówczesnych teoretyków, a jeszcze i później, w głąb I połowy XIX w., teoria Rameau bywała albo niezrozumiana, albo ignorowana ${ }^{76}$. Pomimo znajomości teorii Rameau w omówieniach Sierakowskiego zagadnień harmonii zaznaczają się braki profesjonalnej wiedzy z tego zakresu. Niemały jest także nieporządek pojęciowy obecny w pracach Sierakowskiego $^{77}$. Trzeba jednocześnie zauważyć, że np. zagadnienia metrorytmiczne przedstawił zrozumiale i poprawnie. Dla polskiego piśmiennictwa muzycznego najważniejszym wkładem ks. Sierakowskiego pozostaje wprowadzenie do dziś stosowanej terminologii muzycznej ${ }^{78}$.

\section{Wykład materii podanych na Sejm w roku 1792}

Na końcu I tomu omawianej Sztuki muzyki dołączony został Wykład materii podanych na Sejm w roku 1792 - petycja przygotowana na obrady sejmu w 1792 r. w sprawie objęcia nauczania muzyki protekcją państwową i stworzenia w Krakowie przy katedrze na Wawelu Alumnatus Vocalistarum - centralnej szkoły muzycznej pod patronatem państwowym $^{79}$. Jak wskazuje Tadeusz Przybylski, zalążkiem petycji był dokument (rękopis) z ok. 1790 r., stanowiący Projekt reformy kapeli kościoła katedry wawelskiej, zakładający powołanie Collegium Musicum Cathedrale przy katedrze na Wawelu, w celu zapewnienia dobrze przygotowanych muzyków do śpiewu i gry podczas liturgii ${ }^{80}$. Ks. Sierakowski w 2 lata później, nawiązując do myśli prymasa Poniatowskiego, o której też nadmienił we wspomnianym rękopisie - o pomyśle (niezrealizowanym) powołania szkoły dla organistów, złożył projekt powołania Alumnatus Vocalistarum.

Wykład materii podanych na Sejm w roku 1792 zajmuje 44 strony i rozpoczyna go Głos Muzyki, wprowadzający do kolejnych sześciu rozdziałów. Jako Głos Muzyki w pierwszej osobie przemawia personifikowana muzyka do „Najjaśniejszej Rzplitej sta-

${ }^{75}$ Sierakowski w tomie II Sztuki muzyki odwoływał się bezpośrednio do nazwiska Rameau, wykazując się znajomością Traite de l'harmonie reduite ases peoncipes naturels. T. Przybylski, ,, Sztuka muzyki”..., s. 71.

76 A. Nowak-Romanowicz, Klasycyzm 1750-1830, s. 271.

77 Np. tonację As-dur nazywa „Gis-major”, choć ją oznacza przy kluczu 4 bemolami - tego rodzaju zamieszanie pojęciowe przetrwało do XIX w. i jeszcze ks. J. Jarmusiewicz w Nowym systemie muzyki stosuje wymiennie krzyżyki i bemole, mimo to, że istniał już podręcznik K. Kurpińskeigo, przedstawiający z większą konsekwencją powyższe problemy. T. Przybylski, ,, Sztuka muzyki”..., s. 70.

${ }^{78}$ Są to m.in. takie określenia jak: motyw, modulacja, metryka. T. Przybylski, Z dziejów nauczania, s. 34.

79 P. Kołodziej, [hasło:] Sierakowski Wacław, w: Encyklopedia muzyczna PWM, s. 257. Petycję rozpoczyna Głos do krajowego w Polszcze rzadu, w którym przemawia upersonifikowana Muzyka (w pierwszej osobie), co stanowi ewidentny pośredni wpływ prologów wczesnobarokowych oper włoskich z „L’Orfeo” C. Monteverdiego na czele (1607).

${ }^{80}$ T. Przybylski, Wacław Sierakowski..., s. 59-60. 
nów” w celu roztoczenia opieki państwowej nad nauczaniuem muzyki. Posyłając swoją petycję w roku 1792 do obradującego sejmu, posłużył się zatem ks. Sierakowski na „Wstępie” formą inwokacji ${ }^{43}$.

\begin{tabular}{|c|c|}
\hline $\begin{array}{l}\text { Claudio Monteverdi/Alessandro Striggio (libretto) } \\
\qquad \text { La Musica } \\
\text { L'Orfeo, Mantua } 1607^{42}\end{array}$ & $\begin{array}{c}\text { Wacław Sierakowski } \\
\text { Glos Muzyki } \\
\text { Wykład materyi podanych na Seym w roku 1792, } \\
\text { Kraków } 1792^{43}\end{array}$ \\
\hline $\begin{array}{l}\text { 1. Adresat } \\
\text { Szlachetnej krwi królewskiej herosi, } \\
\text { Których zalety i czyny dziś fama opiewa } \\
\text { Lecz przecie ich mnóstwa nikt wyśpiewać nie zdoła }\end{array}$ & $\begin{array}{l}\text { 1. Adresat } \\
\text { Najjaśniejsze Rzplitej Stany! [...] } \\
\text { Czułość Wasza w niniejszym czasie trwajacego } \\
\text { sejmu każdemu stanowi, owszem każdej osobie } \\
\text { nowy byt nadaje }\end{array}$ \\
\hline $\begin{array}{l}\text { 2. Nadawca } \\
Z \text { miłego Parnasu do was przybywam }[\ldots] \\
\text { Jam jest Muzyka }\end{array}$ & $\begin{array}{l}\text { 2. Nadawca } \\
\text { W tym ośmnastym wieku oświeconym zapomniana, } \\
\text { zaniedbana i opuszczona w Kraju Polskim stawam } \\
\text { przed Wami Muzyka [...] w osobie sieroty, Waszego } \\
\text { wsparcia, Waszej opieki żebrzaca }\end{array}$ \\
\hline $\begin{array}{l}\text { 3. Przymioty muzyki } \\
\text { Ukoić potrafię wszelkie serce strapione } \\
\text { I już to szlachetnym gniewem, już to amorem } \\
\text { Najbardziej mroźny umyst rozpłomienię } \\
\text { [...] } \\
\text { Będę pieściła śmiertelników ucho, } \\
\text { By ku niebiańskich lir harmonii dźwięczacej } \\
\text { Wciąż silniej przyciagać dusze }\end{array}$ & $\begin{array}{l}\text { 3. Przymioty muzyki } \\
\text { Ze wszystkimi żjacymi wrodzony związek majaca } \\
\text { i każdemu dobrze wychowanemu potrzebna } \\
{[\ldots]} \\
\text { Ja sama z osobistych moich przymiotów każdemu } \\
\text { dobrze znana, wszystkich roskosznie bawiaca, } \\
\text { wszystkich ożywiajaca i wpływ mój ledwie nie do } \\
\text { Obrad Waszych mająca }\end{array}$ \\
\hline $\begin{array}{l}\text { 4. Zadanie muzyki } \\
\text { Tedy rzec wam o Orfeuszu jest oto dziś mym } \\
\text { pragnieniem } \\
\text { O tym, który bestie wabil swoim pieniem }\end{array}$ & $\begin{array}{l}\text { 4. Zadanie muzyki } \\
\text { Religia panujaca, której ja największa cześć } \\
\text { wyrządzam i jej całe ustugi moje poświęcam }\end{array}$ \\
\hline $\begin{array}{l}\text { 5. Zwroty końcowe } \\
\text { Teraz gdy pieśni me snuję, to radosne, to smutne, } \\
\text { Niech nawet ptak pośród tych krzewów nie zakwili, } \\
\text { I u brzegów tych niech nie szemrze plusk fali } \\
\text { A tchnienie wiatru niechaj zastygnie w swym biegu. }\end{array}$ & $\begin{array}{l}\text { 5. Zwroty końcowe } \\
\text { Ciebie jeszcze Łaskawa Publiczności, która } \\
\text { najlepsze o rzeczach i osobach współczesnych } \\
\text { umiesz dawać zdanie, za obronicielkę stanu } \\
\text { sierocego mojego i przewodniczkę do tej Praw } \\
\text { Światyni, do której ja po kolędzie w roku } 1792 \\
\text { przychodzę, przybieram sobie. Twojemu przewod- } \\
\text { nictwu ufam, iż pożadany skutek głosu mojego } \\
\text { odniosę. }\end{array}$ \\
\hline
\end{tabular}

Głos Muzyki przypomina w pewien sposób barokowe ujęcie walorów tej sztuki przedstawione w prologu (Dal mio Parnasso) do opery „L'Orfeo” Claudia Monteverdiego

43 Jak ujął to ks. Tadeusz Przybylski. T. Przybylski, ,,Sztuka muzyki”,.., s. 76.

${ }^{42}$ Libretto opery L'Orfeo C. Monteverdiego w przekładzie na język polski zob. The Third Claudio Monteverdi Festival in Warsaw, Warszawa 29.09-10.10.1999, s. 23.

${ }^{43}$ W. Sierakowski, Wykład materyi podanych na seym $w$ roku 1792, w: Sztuka muzyki dla młodzieży kraiowey, s. 159-162. 
(Mantua 1607), choć ks. Sierakowski nie mógł znać tego dzieła, to pewne wpływy konwencji włoskiej opery barokowej sprzed prawie 200 lat są tu zauważalne. Jedna jest podstawowa różnica - pomimo przedstawionych u obydwu walorów muzyki - u Monteverdiego muzyka jawi się jako dumna muza, u Sierakowskiego - jest to zaniedbana i opuszczona w Kraiu Polskim [...] sierota żebrzaca.

Inny jest także kontekst, kraj i realia epoki. L'Orfeo Monteverdiego powstało dla dworu Gonzagów w Mantui z okazji karnawału w 1607 r. Celem było dostarczenie rozrywki wąskiemu gronu arystokratycznego dworu. Rolą Muzyki jest wprowadzenie publiczności do dzieła nowego rodzaju, jakim była dramma per musica, podejmującego temat mitu Orfeusza - człowieka, który za pomocą muzyki zdołał przejednać bogów. La Musica zwraca się zatem do arystokratycznego grona odbiorców, napominając o ich zasługach (nie istotne na ile rzekomych). Jest postacią dumną i silną, która zstąpiła z samego Parnasu (choć imię Melpomeny się tu nie pojawia, La Musica bowiem jest czymś więcej, niż jedynie muzą tragedii i śpiewu). Wie doskonale, jaką ma moc oddziaływania, potrafi „ukoić”, „rozpromienić”, „pieścić” i ,przyciągać”. Na koniec zaś nawet napomina (jednak nie bezpośrednio nobilitowaną publiczność, lecz przyrodę), aby kiedy ona zabiera głos, nikt nie ośmielił się go zakłócać.

Dziełko Sierakowskiego powstało w całkiem innej epoce, kraju i kontekście. Przede wszystkim nie jest to opera, lecz tekst bez muzyki, ujęta w ramy utworu literackiego petycja. Jednakże Głos Muzyki także i w tym wypadku stanowi wprowadzenie - z tym, że u Sierakowskiego - do wniosku skierowanego do sejmu. W okresie obradowania Sejmu Czteroletniego zwraca się zatem do niego Muzyka, aby oddać się pod jego protekcję, przypominając swoją upokorzoną rolę i upadek, związany z jej porzuceniem w trwającym wciąż wieku XVIII. To, co łączy ją z personifikacją muzyki z barokowej opery włoskiej, to nadal aktualna świadomość oddziaływania na zmysły człowieka - potrafi być rozkosznie bawiąca i ożywiająca oraz wpływ mająca (lecz nie na obrady sejmu). Przy tym - odwołując się do obecnego w epoce oświecenia etosu wykształcenia - jest każdemu dobrze wychowanemu potrzebna. Warto przy tym nadmienić, że ks. Grzegorz Piramowicz także dostrzegał zdolność muzyki w ,wywoływaniu wesołości”, co uważał za pożądane, widząc potrzebę wprowadzenia w szkołach lekcji śpiewu ${ }^{44}$. Do głównych zadań muzyki w ujęciu ks. Sierakowskiego należy wyrządzanie czci obrzędom religijnym. Na końcu Głos Muzyki zwraca się także do publiczności, prosząc ją o wsparcie. Nie posiada ona jednak w żadnej mierze dumy i splendoru swojej personifikacji z początku wieku XVII, stając się w Rzeczypospolitej końca XVIII w. „żebraczką” świadomą jedynie należącej się jej zaszczytnej roli. Zastosowany przez Sierakowskiego chwyt retoryczny, polegający na użyciu formy inwokacji, ma dla nas jednocześnie wagę dokumentu

44 Dzieci nie moga być zdrowe bez wesołości [...] Pomoże do wesolości zwyczaj śpiewania wprowadzać. Piramowicz postulował wprowadzenie wychowania muzycznego dzieci w szkółkach parafialnych oraz nauczania muzyki w seminariach nauczycielskich. K. Mazur, Miejsce muzyki w założeniach reformy edukacji narodowej, w: PWSM w Warszwie, Sesja naukowo-artystyczna: Wychowanie muzyczne narodu w 200 rocznice Komisji Edukacji Narodowej, Warszawa 1976, s. 24. 
historycznego, obrazującego obojętność XVIII-wiecznego polskiego społeczeństwa wobec zagadnień dotyczących muzyki ${ }^{45}$.

W kolejnych rozdziałach Wykładu materyi podanych na Seym w roku 1792 przedstawione są postulaty zasygnalizowane przez Głos Muzyki: I. Zacność muzyki, II. Ninieysze upodlenie teyże, III. Jej potrzeba, IV. Rozgatunkowanie, V. Konieczność uformowania jednego ciała, VI. Sposoby założenia i utrzymywania tego funduszu. W ten sposób Sierakowski uzasadnia potrzebę objęcia zainteresowania muzyką i koniecznością opieki państwowej nad muzyką, zwłaszcza nad szkolnictwem muzycznym.

Po przedstawieniu niskiego stanu kultury muzycznej w Polsce, a także potrzebie jego poprawy oraz pojawiającemu się następnie podziale muzyki na poszczególne gatunki, w rozdziale V uzasadniał Sierakowski konieczność powołania w Krakowie ogólnopolskiej szkoły muzycznej pod patronatem państwowym. Było to istotne zwłaszcza wobec faktu, że szkolnictwo muzyczne w Rzeczypospolitej w owym czasie stanowiło twór bardzo niejednolity, składający się z rozmaitych form organizacyjnych - szkół prywatnych, pensji, seminariów nauczycielskich, z których wiele działało jedynie przez krótki okres ${ }^{46}$. Sierakowski uzasadniał potrzebę scalenia i scentralizowania działań zmierzających do poprawy tego stanu rzeczy: Tak rozproszona po całym kraju muzykantów liczbę, w jedno rzadne ciało zebrać potrzeba, pod jedna głowę; aby to zgromadzenie mogło się utrzymywać i służyć na zawsze Krajowi. W ten sposób powołać chciał w Krakowie Alumnatus Vocalistarum $^{47}$. Szkoła miała być przeznaczona dla 60 uczniów - z równym podziałem na: 20 „dzieci szlacheckich”, 20 „dzieci miejskich” i 20 „dzieci włościanów”, przyjmowanych nie żadna rekomendacja lub innym nieprzyzwoitym sposobem [...], ale jedynie $z$ wrodzonej sposobności do śpiewania. Edukacja miała się rozpoczynać w wieku 7 lat i trwać przez lat $8^{48}$. Kryterium przyjęcia uczniów miały stanowić wyłącznie naturalne predyspozycje do uprawiania muzyki, a więc: „dobry wzrok”, ,pierś wolna”, „wymowa jasna”, „ucho prędkie”, „dobre czytanie” [sic!] „takt”, „pojętność i ochota”. Sierakowski zdając sobie sprawę, ile zaangażowania wymaga edukacja muzyczna, podkreślał, że kryteria te służą właśnie temu, aby próżno i fundacji i dzieci nie zawodzić biorąc niesposobnych ${ }^{49}$.

Ks. Sierakowski wyznawał zatem poglądy społeczne daleko wybiegające naprzód W stosunku do ogólnie panujących, nie uznając żadnych preferencji uwarunkowanych pochodzeniem uczniów ${ }^{50}$. Zamierzał traktować jednakowo dzieci wszystkich stanów, za-

${ }^{45}$ Zdaniem T. Przybylskiego inwokacja ta obrazuje obojętność społeczeństwa $w$ czasach saskich - jednak już od prawie 30 lat panował na tronie polskim S. A. Poniatowski, zatem co najwyżej możemy zgodzić się, że obojętność ta w dużej mierze trwała nadal, pomimo powstania w czasach stanisławowskich kilku polskich oper. T. Przybylski, , Sztuka muzyki”..., s. 76.

${ }^{46}$ K. Mazur, op. cit., s. 23.

${ }^{47}$ W. Sierakowski, op. cit., s. 190.

48 Ibidem, s. 191, 194.

49 Ibidem, s. 192.

50 T. Przybylski, Wacław Sierakowski..., s. 62. 
strzegając jedynie sprawdzenie ich zdolności i umiejętności, niezależnych od pochodzenia - może za wyjątkiem ,wymowy jasnej” i „dobrego czytania”.

Proces kształcenia odbywać się miał na 3 poziomach: „zaczynających”, ,postępujących” i „doskonałych”. Jako najlepsze miejsce dla planowanej szkoły uznał Sierakowski Kraków, widząc potrzebę także pozamuzycznego wykształcenia uczniów - aby uczacy się muzyki zaraz chodzili do szkół publicznych $i$ w innych ćwiczyli się naukach ${ }^{51}$. Sierakowski przewidywał, że nowo powołana szkoła wykształci doskonałych śpiewaków, instrumentalistów, kompozytorów „sławnych”, ale także i kopistów „wprawnych”. Jednocześnie, dzięki podniesieniu w kraju liczby wyedukowanych muzyków, ustanie potrzeba sprowadzania wielkim kosztem obcych. Sierakowski w powołaniu szkoły widział główny ratunek dla polepszenia stanu muzyki kościelnej, nad którym niejednoktrotnie ubolewał ${ }^{52}$. Miał na tym polu już pewne doświadczenie, prowadząc przez 6 lat przy katedrze na Wawelu szkołę śpiewu.

Wacław Sierakowski poza powołaniem szkoły planował cały system utrzymujący i nadzorujący nową placówkę. Nad alumnatem miało mieć dozór Kolegium Muzyczne złożone z przedstawicieli stanu duchownego, szlacheckiego, ,żołnierskiego” i mieszczańskiego, do którego obowiązków miały należeć: zwierzchność i dozór, dokonywanie sądów, rad oraz sesji poświęconych alumnatowi, prowadzenie ewidencji wszystkich uczniów, a także pilnowanie, aby zagraniczni muzycy nie odbierali stanowisk muzykom polskim chyba po danej prośbie, za ich aprobata, wydawanie ,patentów” dla absolwentów, chcących robić karierę za granicą, zabezpieczenie losu nieletnich muzyków ${ }^{53}$. W projekcie nowego systemu Sierakowski widział poprawę stanu muzyki, odwołując się w ten sposób do upadku pozycji tej sztuki wyrażonego wcześniej przez Głos Muzyki. Pisał zatem: Tak urzadzona muzyka w Polszcze, byłaby $i$ doskonalsza i szanowniejsza, mniejby żywiła ludzi, ale pewniejszych i nierozpustnych ${ }^{54}$. Uważał Sierakowski, że lepiej, aby było mniej muzyków - lecz gruntowniej wykształconych, dzięki czemu poprawiłby się stan kultury muzycznej w kraju.

W rozdziale VI Sierakowski postulował potrzebę powołania funduszu przeznaczonego na prowdzenie alumnatu, przywołując istnienie podobnego rodzaju funduszy szpitalnych. Prócz rodziców zdolnych opłacać edukację swych dzieci, także kościoły (wszystkie katedry, kolegiaty i główniejsze opactwa) miałyby skierowywać do Krakowa uczniów, płacąc na edukację tylu ile im potrzeba, gdy tej tu normalnej szkoty najda wygode $e^{55}$. Ks. Sierakowski, posiadając doświadczenie w prowadzeniu przez 6 lat prywatnej szkoły śpiewu - utrzymywanej własnym sumptem - wiedział, że przez dłuższy czas zamierzenie takie nie jest możliwe bez odpowiednich funduszy z zewnątrz ${ }^{56}$.

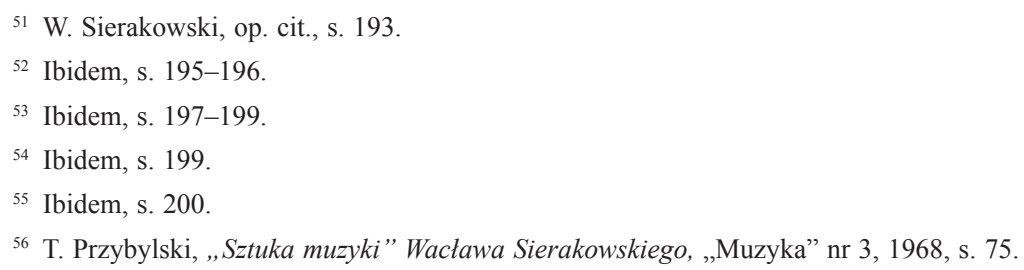


Petycja zawarta w Wykładzie materyi podanych na Seym pozostała wyłącznie na papierze, mimo że ks. Sierakowski w 1792 r. złożył ją w sejmie ${ }^{57}$. Bieg wypadków politycznych uniemożliwił bowiem jej zrealizowanie i nie była ona rozpatrywana przez sejm, zajęty innymi sprawami, wobec rozpadającej się państwowości i konieczności szukania środków naprawy istniejącej sytuacji, zaś następujące kolejne rozbiory Rzeczypospolitej ostatecznie przekreśliły możliwość jej realizacji ${ }^{58}$. Planowane zatem powołanie w Krakowie wzorcowej szkoły muzycznej - Alumnatus Vocalistarum nigdy nie zostało zrealizowane ${ }^{59}$.

Ks. Wacław Sierakowski odegrał niewątpliwie dużą rolę w życiu muzycznym Krakowa, powołując szkołę muzycznę, organizując koncerty i przedstawienia operowe. Efektem zainteresowania problematyką edukacji muzycznej w Polsce stała się 3-tomowa Sztuka muzyki, wraz z powstałym wcześniej Wykładem materii podanych na seym $w$ roku 1792.

Wykład materyi podanych na Seym wpisuje się doskonale w kontekst wyznaczony przez działalność Komisji Edukacji Narodowej. Z jednej strony bowiem działalność komisji - stawiającej nacisk głównie na przedmioty ścisłe - doprowadziła do usunięcia z programów szkolnych naukę wielu przedmiotów stricte teoretycznych (jakim była muzyka wykładana w wydaniu scholastycznym, obecnym na Akademii Krakowskiej jeszcze do czasów oświecenia) ${ }^{60}$, z drugiej - zainspirowała do zajęcia się edukacją muzyczną w wymiarze praktycznym, o czym najlepiej świadczy projekt powołania Alumnatus Vocalistarum. Zresztą potrzebę istnienia szkoły muzycznej ks. Sierakowski ujął także we wstępie do samej Sztuki muzyki.

Zgodny z duchem oświecenia był również sam zamysł napisania podręcznika do muzyki. W opinii Komisji Edukacji Narodowej to właśnie dobry podręcznik miał odgrywać decydującą rolę w procesie nauczania (nawet w rękach źle wykształconego nauczyciela). W okresie działanie KEN nie zdołano jednak wydać podręcznika sztuk i rzemiosł ${ }^{61}$. W takiej sytuacji traktowanie muzyki jako przedmiotu, jego program i sposób realizacji

57 E. Aleksandrowska, [hasło:] Sierakowski Wacław, w: Polski słownik biograficzny, s. 314.

58 P. Kołodziej, [hasło:] Sierakowski Wacław, w: Encyklopedia muzyczna PWM, s. 257. T. Przybylski, „Sztuka muzyki”..., s. 59.

${ }^{59}$ Prowadzona zaś przez Sierakowskiego w latach 1781-1787 szkoła z planowanym w 1792 r. alumnatem nie miała nic wspólnego, o czym przypomniał Tadeusz Przybylski, prostując informację zawartą w literaturze przedmiotu na ten temat. T. Przybylski, ,, Sztuka muzyki”..., s. 74.

${ }^{60}$ Historia nauki polskiej, red. B. Suchodolski, t. IV, cz. 1-2, Wrocław 1987, s. 112. W okresie reform KEN duże zmiany przeszła szkoła teologiczna, w której nastąpiło odejście od metody scholastycznej na rzecz przyjęcia metody opartej na racjonalnym ujmowaniu problemów. Kształcenie zgodnie z nauczaniem Kościoła starano się zaś łączyć z wychowaniem obywatelskim, z akcentem położonym na dostrzeganie obowiązków wobec kraju i narodu. K. Mrozowska, Funkcjonowanie systemu szkolnego Komisji Edukacji Narodowej na terenie Korony w latach 1783-1793, Wrocław 1985, s. 50.

${ }^{61}$ R. Dutkowa, Komisja Edukacji Narodowej. Zarys działalności, wybór materiałów źródłowych, Wrocław 1973 , s. 44 i 47. 
zależały właściwie od inwencji i możliwości samych nauczycieli, pozbawionych odpowiedniego podręcznika, zaś wytyczne programowe Komisji Edukacji Narodowej były zbyt ogólnikowe w tym względzie. Dlatego na przestrzeni 20 lat istnienia Komisji sprawa nauczania muzyki przedstawiała się rozmaicie w szkołach różnych szczebli, z występowaniem także różnic lokalnych ${ }^{62}$. Inną sprawą jest, że Sierakowski nie zdawał sobie przy tym sprawy, ile błędów i niekonsekwencji zawiera jego Sztuka muzyki.

Fakt sporządzenia podręcznika w języku polskim miał też związek z silną wówczas tendencją przekazywania wiedzy w języku narodowym. Choć nie był to jednak pierwszy polski podręcznik do muzyki, jak utrzymywał Sierakowski (o tej wyzwolonej nauce muzyki, nikt dotąd $w$ polskim języku z urzędu nie mówit $)^{63}$, to z pewnością pojawił się po długim czasie braku tego rodzaju literatury. Zastosowanie języka polskiego w wywodach na temat muzyki także wpisuje się w kontekst reformy edukacyjnej zaprowadzonej przez KEN, bowiem, pokolenie, które wyszło ze zreformowanych placówek biegle łaciną już nie władało ${ }^{64}$. Wiele miejsca w swoim podręczniku poświęca Sierakowski także praktycznemu zastosowaniu (w śpiewie) wiedzy muzycznej, co zbliża go do podejścia oświeceniowego stosowanego w naukach ścisłych - wiedzy opartej na doświadczeniu, dopełnionej wiadomościami o naukach, kunsztach i rzemiosłach ${ }^{65}$. Podręcznik Sierakowskiego ma zatem w wielu miejscach praktyczny charakter, mimo nie jednorazowych odwołań autora do średniowiecznego pojęcia sztuk wyzwolonych, a więc niepowiązanych bezpośrednio z doznaniem empirycznym. W zakresie teorii muzyki widoczny jest też wpływ XVIII-wiecznych francuskich teoretyków muzyki - J.F. Rameau i J.J. Rousseau, zaś z pierwszym z nich zdarza się też Sierakowskiemu polemizować.

Podręcznik Sierakowskiego rozpowszechniony został na ziemiach polskich w ciągu pierwszej połowy XIX w. Także we Lwowie, co poniektórzy ślęczeli nad Sztuką muzyki dla młodzieży krajowej. Była to w Galicji na początku XIX w. jedyna dostępna pozycja w języku polskim, zanim został rozpropagowany Wykład systematyczny zasad muzyki na klawikord Karola Kurpińskiego $(1818)^{66}$.

Działalność ks. Sierakowskiego na rzecz upowszechniania wiedzy w okresie oświecenia budzi też skojarzenia z postacią działającego równolegle w Polsce centralnej ks. Jana Krzysztofa Kluka (1739+1796), proboszcza w Ciechanowcu, autora Botaniki dla szkół narodowych (Warszawa 1785), który także jako entuzjasta i amator, publikował na tematy związane z zoologią i botaniką, chcąc w ten sposób przyczynić się do popularyzacji wiedzy w tym zakresie.

Jak zauważył Tadeusz Przybylski, ks. Sierakowski, rozumiejąc wagę idei Komisji Edukacji Narodowej, postulującej rolę nowoczesnego wychowania młodego obywatela, zdawał sobie sprawę, że w wychowaniu nie może zabraknąć elementu etycznego, dostrzegając go w nauczaniu muzyki. Podkreślano bowiem wówczas powszechnie rolę

\footnotetext{
${ }^{62}$ A. Rutkowska, Realizacja planów i postulatów Kom EN..., w: PWSM w Warszwie, s. 32 i 35.

${ }^{63}$ W. Sierakowski, op. cit., s. 9.

${ }^{64}$ R. Dutkowa, op. cit., s. 39

65 Ibidem, s. 37.

${ }^{66}$ J. T. Pekacz, Music in the Culture of Polish Galicia 1772-1914, Rochester 2002, s. 152.
} 
szkoły w kształceniu charakteru i wdrażaniu do życia w społeczeństwie ${ }^{67}$. Dlatego właśnie napisał w 1792 r., pod koniec obrad Sejmu Czteroletniego, obszerną petycję, przedstawiając obradującym stanom konieczność wprowadzenia do szkół wychowania muzycznego, mecenatu państwa nad muzyką oraz powołania szkoły muzycznej pod kuratelą państwa $^{68}$. Wychowawczy i oświeceniowy charater ma także sama Sztuka muzyki. Działalność ks. Sierakowskiego uzupełnia zatem - choć w marginalny sposób - zaniedbanie jakie dotknęło muzykę z rąk Komisji Edukacji Narodowej. W jej składzie brakowało osoby przejawjącej większe zainteresowanie muzyką, zaś Sierakowski nie znalazł się nawet w gronie współpracowników Komisji. Jak uważa Krzysztof Mazur niewykluczone, że członkowie KEN byli pod wpływem pewnych negatywnych zjawisk towarzyszących nauczaniu muzyki w swoim środowisku, mogąc mieć przykre doświadczenia związane z uprawieniem muzyki przez „utytułowane amatorki”, czy też poziomem umysłowym ówczesnych pedagogów muzycznych ${ }^{69}$. Dlatego też edukacji muzycznej Komisja Edykacji Narodowej poświęciła najmniej miejsca.

Tadeusz Przybylski podkreśla, że Sztuka muzyki Sierakowskiego nie nawiązywała bezpośrednio do tradycji. Jest to uzasadnione ze względu na lukę powstałą na przestrzeni ponad 100 lat w polskim piśmiennictwie muzycznym. Po tak znacznej przerwie na tym polu zagadnieniem tym zajął się nie fachowiec, lecz amator i laik - jak Przybylski określa muzyczne wykształcenie Sierakowskiego w świetle jego wypowiedzi i poglądów. Warto dodać, że w okresie oświecenia także ks. Grzegorz Piramowicz w ostatnich latach swojego życia przygotowywał w zamierzeniu dydaktyczny zbiorek pieśni Piosenki dla pociechy ludu, ostatecznie jednak nie wydany ${ }^{70}$. Nie miał to być jednak w swej zasadniczej części podręcznik do teorii muzyki, a jedynie zbiór pieśni przeznaczony dla szkół podczas lekcji śpiewu, których wprowadzenie postulował. Trzeba zauważyć, że to Sierakowski pierwszy dokonał w Polsce podziału instrumentów muzycznych, po raz pierwszy posłużył się też do dziś stosowaną terminologią (motyw, modulacja, metryka), oraz jako kolejny polski teoretyk dokonał również podziału gatunków muzycznych. Główną zasługą była niewątpliwie przyświecająca mu intencja wzbudzenia zainteresowania muzyką wśród społeczeństwa i docenienie roli szkolnictwa muzycznego dla kultury muzycznej $\mathrm{kraju}^{71}$. Dla historii muzyki praca Sierakowskiego do dziś stanowi szczególną wartość jako źródło informacji o stanie polskiej kultury muzycznej ostatnich lat istnienia Rzeczypospolitej.

\footnotetext{
${ }^{67}$ R. Dutkowa, op. cit., s. 39.

${ }^{68}$ T. Przybylski, Wactaw Sierakowski..., s. 59.

${ }^{69}$ K. Mazur, Miejsce muzyki..., w: PWSM w Warszawie, s. 26-27.

${ }^{70}$ A. Rutkowska, Realizacja planów i postulatów Kom EN..., w: PWSM w Warszawie, s. 41.

71 T. Przybylski, ,,Sztuka muzyki”..., s. 76-77.
} 


\section{Bibliografia}

Aleksandrowska E., Sierakowski Wacław, w: Polski słownik biograficzny, red. H. Markiewicz, t. XXXVII, Kraków 1996-1997.

Chybiński A., Przyczynki do historii krakowskiej kultury muzycznej w XVII i XVIII wieku, „Wiadomości Muzyczne" 1925, nr 7.

Dutkowa R., Komisja Edukacji Narodowej. Zarys działalności, wybór materiałów źródłowych, Wrocław 1973.

Dziębowska E., Riemann Hugo, w: Encyklopedia muzyczna PWM, red. E. Dziębowska, t. 8, Kraków 2004.

Encyklopedia Krakowa, red. D. Kalisiewicz, Kraków 2000.

Historia nauki polskiej, red. B. Suchodolski, t. IV, cz. 1-2, Wrocław 1987.

Jachimecki Z., Muzykologia i piśmiennictwo muzyczne w Polsce, Kraków 1949.

Jarzębska A., Rameau Jean-Philippe, w: Encyklopedia muzyczna PWM, red. E. Dziębowska, t. 8, Kraków 2004.

Kochanowicz J., Geneza, organizacja i działalność jezuickich burs muzycznych, Kraków 2002.

Kołodziej P., Sierakowski Wacław, w: Encyklopedia muzyczna PWM, red. E. Dziębowska, t. 9, Kraków 2007.

Mazur K., Miejsce muzyki w założeniach reformy edukacji narodowej, w: PWSM w Warszawie, Sesja naukowo-artystyczna: Wychowanie muzyczne narodu w 200 rocznice Komisji Edukacji Narodowej, Warszawa 1976.

Mrozowska K., Funkcjonowanie systemu szkolnego Komisji Edukacji Narodowej na terenie Korony w latach 1783-1793, Wrocław 1985.

Nowak-Romanowicz A., Gołąek Jakub, w: Encyklopedia muzyczna PWM, red. E. Dziębowska, t. 3, Kraków 1987.

Nowak-Romanowicz A., Klasycyzm 1750-1830, Warszawa 1995.

Pekacz J. T., Music in the Culture of Polish Galicia 1772-1914, Rochester 2002.

Prosnak J., Kultura muzyczna Warszawy XVIII wieku, Kraków 1955.

Przybylski T., ,Sztuka muzyki” Wacława Sierakowskiego, „Muzyka” 1968, nr 3.

Przybylski T., Wacław Sierakowski - działacz muzyczny Krakowa czasów Oświecenia (1741-1806), „Muzyka” 1971, nr 1.

Przybylski T., Z dziejów nauczania muzyki w Krakowie. Od średniowiecza do czasów wspótczesnych, Kraków 1994.

Rutkowska A., Realizacja planów i postulatów Kom EN w zakresie wychowania muzycznego, w: PWSM w Warszawie, Sesja naukowo-artystyczna, Wychowanie muzyczne narodu w 200 rocznice Komisji Edukacji Narodowej, Warszawa 1976.

Sierakowski W., Sztuka muzyki dla młodzieży krajowej, t. I, Kraków 1795.

Sowiński A., Słownik muzyków polskich dawnych i nowoczesnych, Paryż 1874.

The Third Claudio Monteverdi Festival in Warsaw, Warszawa 1999. 
